\title{
Cevdet AŞKIN
}

Dr. |Dr.

İstanbul Milli Eğitim Müdürlüğü Eğitim Uzmanı, İstanbul-Türkiye Educational Specialist of Istanbul Directorate of National Education, İstanbul-Türkiye cevcanbur@hotmail.com

\section{BİRINCİ DÜNYA SAVAŞI BOYUNCA GÜMÜŞHANE VE ÇEVRESİNDE RUS İŞGALI'NIIN SOSYAL YANSIMASI}

\begin{abstract}
Özet
Birinci Dünya Savaşı sırasında Rus işgal kuvvetlerinin Trabzon Limanı'nı ele geçirmek istemesinin iki nedeni vardı. Birinci hedef Osmanlı Ordusu'na gidecek lojistik desteği kesmekti. İkinci sebep ise, Rus işgal kuvvetlerine destek sağlamasıydı. Rus Ordusu bu işgal sırasında yer yer büyük direnişlerle karşılaştı. Rusların Gümüşhane ve çevresindeki yerleşim yerlerinde sosyal, ekonomik, dinî ve kültürel bakımdan kalıcı ve yıkıcı tesirleri olmuştur. Rus işgaliyle aileler parçalanmış, taşınmaz kültür varlıkları zarar görmüştür. Rus Ordusu'nun pek çok sivili öldürmesi ve sivil halkın kahramanlıkları, halk türkülerine ve hikâyelerine konu olmuştur. Bu çalışmada, sözü edilen olaylar, arşiv belgeleri, dergiler ve kitaplarda yer alan bilgiler, sözlü anlatımın derlenmesi suretiyle gerçekleştirilmiştir.
\end{abstract}

Anahtar Kelimeler: Osmanlı Devleti, Rusya, İşgal, Muhacir, Şehit, Savaş.

\section{SOCIAL REFLECTION OF THE RUSSIAN INVASION AROUND GÜMÜŞHANE DURING THE FIRST WORLD WAR}

\begin{abstract}
There were two reasons of capture of Trabzon port by Russian forces during the First World War The first reason was to cut off logistical support to the Ottoman Army. The second reason was to provide logistic support to the Russian forces. Russian army has faced many great locality resistances during the occupation. Russian Armies made permanent and devastating effects such as social, economic, religious, culturally in many aspects in Gümüşhane and around settlements. Because of Russian invasion, families were broken and immovable cultural properties were damaged. Russian army's killing many civilians and heroism of civilian population has been the subject of folk songs and stories. In this paper, the events in point, archive documents, information in books and magazines were done by means of editing of oral narrative.
\end{abstract}

Keywords: Ottoman Empire, Russia, Occupation, Muhajir, Martyrs, Battle. 


\section{GíRIŞ}

\section{Türkiye'nin Rusya İle Uyuşma Arayışları}

Türkiye-Rusya ilişkileri oldukça eskiye dayanan bir dönemi kapsar. Bilhassa Rusya'nın XVIII. yüzyıldan itibaren güçlenmesi, Çar I. Petro ile sıcak denizlere ulaşma arzusu Osmanlı İmparatorluğunun toprak bütünlüğünü tehdit eden bir gelişme olmuştur. XIX. yüzyıl boyunca Rusya'nın bu hedefe ulaşmak için Osmanlı Devlet'ine defalarca büyük savaşlar açtığını görmekteyiz.

1908 yılında Rus Çarlığı İstanbul Boğazını ele geçirmeyi planlamıştı. Çünkü bu sırada Almanya'nın Osmanlı üzerindeki nüfuzu Rusya'yı endişelendirmişti. Rus Dışişleri Bakanı Sazanov İstanbul'daki elçisi Giers'e Türkiye'ye karşı takip edilecek strateji hakkında kapsamlı bir talimat göndermişti. Aynı tarihlerde Enver Paşa ve Sadrazam Talat Paşa, savaşa girmemek amaciyla Rusya ile bir antlaşma yapmayı düşünmekte veya en azından bunu tasarlamaktaydı. Bunun için 5-14 Ağustos 1914'de İstanbul ve Petersburg'da bazı temaslarda bulunuldu. Petersburg'daki Türk Elçisi Fahreddin Paşa, Enver Paşa’nın Rusya tekliflerini Sazanov’a bildirdi. Ancak, Osmanlının Rusya ile anlaşması bir anlamda İstanbul'dan vazgeçmesi demek olduğundan görüşme reddedildi. Bunu takiben Osmanlı Devletiyle Almanya arasında 2 Ağustos 1914 tarihinde gizli bir antlaşma imzalandı. Bu sırada "Goeben" ve "Breslau" (Yavuz-Midilli) adlı Alman savaş gemilerinin Osmanlı Devletine sığınarak satın alınmaları Rusya ile müttefiklerinin dikkatini çekti. Bu arada Almanların komutasındaki Osmanlı donanması 29-30 Ekim tarihlerinde Odesa, Sivastopol, Feodosya, Novarossiysk ve Batum kıyılarını bombaladı" (Kurat 2014: 441-442). Hazırlıksız olduğundan savaşa girmesi henüz düşünülmeyen Osmanlı Devleti, Almanya-Avusturya-Bulgaristan'la ittifak yoluna gitti (Sonel 1987: 1). Öncelikle 2 Kasım 1914'de Rusya ve takiben Fransa ve İngiltere'nin yer aldığı İtilaf Devletleri 5 Kasım 1914 günü Osmanlıya savaş ilan ettiler. Savaş başlayınca Gürcistan üzerinden Kars ve Ardahan dâhil olmak üzere Ruslar Doğu Anadolu'yu işgale başladılar (Yı1dız 2007: 40). 


\section{Kafkas Cephesi'ndeki Savaşlar}

Asya ve Avrupa kıtaları arasında bir sınır görevi gören ve önemli coğrafi konuma sahip olan Kafkasya, tarihî bakımdan köklü bir geçmişe sahiptir. Türk-Rus ilişkilerinde Kafkasya, jeopolitik ve jeostratejik açıdan büyük bir önem arz etmiştir.

Osmanlı Devleti I. Dünya Harbine Almanya'nın müttefiki olarak katıldı. Dönemin Genel Kurmay Başkanvekili Enver Paşa Kafkas Cephesi’nde Ruslara karşı savaş ilan etti. Bunu gören Genel Kurmay Başkanvekili Enver Paşa Kafkas Cephesi'nde Ruslara karşı savaş ilan etti. Türk kuvvetleri Rus sınırını birkaç noktadan geçmeye başladı. Devamında Kars'ın güneyindeki Köprü Köy civarında Ruslarla olan savaş şiddetlendi ve 10 Kasım 1914'te Artvin, Çoruh, Ardahan ve Oltu Rusların eline geçti (Kurat 2014: 444). Silah, mühimmat ve donanım yetersizliğine rağmen Enver Paşa taarruzu devam ettirdi. Ancak, mevsim kış olduğundan, gerekli mühimmat ve teçhizat bölgeye taşınamayıp buna planlama yetersizliği eklenince Allahuekber Dağlarında 39 bin asker soğuktan donarak şehit düşmüş ve Türklerin kayıpları toplam 60 bine varmıştı (Türk Ansiklopedisi 2001: 159). Türkler, Sarıkamış ve civarında devam eden muharebelerde çok zayiat ve esir verince Ruslar kaybettikleri yerleri yeniden işgal ettiler.

Kafkas Genel Valisi ve Rus Orduları Başkomutanı olan Nikola Nikolayeviç yeniden taaruza geçti. Akabinde Ocak-1916'da, Ruslar harekete devam ederek Bağdat Demiryolunu ele geçirmek ve Almanların İran'la ittifakını önlemek amacıyla İran Azerbaycan'ına girdiler. Buna karş1lık Türk ordusu erken davranarak Tebriz'e girdi. Ruslar, saldırıya devam ederek Şubat 1916'da Erzurum'u işgal ettiler. Buna paralel olarak Muş ve Bitlisi de ele geçirdiler. Bu işgal Karadeniz sahili boyunca devam etti Kurat 2014: 444-445).

$\mathrm{Bu}$ harekât sonunda Picot ve Sykes Antlaşmasına bağlı olarak onaylanan Petrograt Sözleşmesiyle Tirebolu'nun güneyine kadar uzanan hattın (Harşit Çayı ağzı) doğusunda kalan topraklar Rusya'ya bırakıldı. Rusya işgal ettiği Batum ve Kars civarında tahkimata devam etti. Türk Genel Kurmayı ise iki koldan Rus birliklerinin saldırısını görünce, halkı teşkilatlandırmak amacıyla Avni Paşa'yı Of'a, Halit Paşa'yı da Bayburt'a gönderdi. Avni Paşa Of’a varınca, Domuz (İkizdere) Çayı boyunca Kelali Köyü 
civarında yeni bir savunma cephesi kurdu. Aynı tarihte Halit Paşa da Bayburt'un Çoruh Vadisi'nde bulunan Hozaspur, Müşeverek Köyleri civarında direniş cephesi oluşturdu. 16 Şubat 1916 günü Rus harekâtına karşı Batum ve Kars yönünde Rize civarında herhangi bir direniş görünmedi. 6 Mart 1916'da Pazar, Ardeşen, Çayeli'ni, 8 Mart'ta da Rize'yi işgal ettiler (Özol 1991: 5).

Avni Paşa'nın uyguladığı savaş stratejisi karşısında Rus kuvvetleri durakladı. Rus kuvvetleri, Avrupa cephesinde savaşan 35 bin kişilik askeri birliklerini takviye ederek 16 Mart'ta saldırıya geçtiler. Ancak büyük bir dirençle karşılaştılar. Fakat deniz kuvvetlerinden de aldıkları destekle 14 Nisan akşamı direniş cephesini yararak Of’a girdiler. Direnişin zayıflamasıyla Ruslar, kolayca Tirebolu'ya kadar olan bütün sahil hattını işgal ettiler (Türk Ansiklopedisi 2001: 380).

16 Şubat 1916'da Erzurum'un işgali ile Enver Paşa 3. Ordu Komutanı Mahmut Kemal Paşa'yı görevden alarak, yerine Çanakkale'nin başarılı komutanı Vehip Paşa'yı komutanlığa atadı. Paşaya verilen görev, Tercan'ın batısından itibaren Bayburt'un doğusu ve Trabzon'un batı hattına kadar ilerlemiş olan Rus ordusunu durdurmaktı. 1916 Mayıs başında Vehip Paşa'nın emrinde 130 bin asker ile 200 top varken, Rus Generali Yudenich'in emrinde 200 bin asker ile 400 top bulunuyordu (San 1987: 24). 16 Haziran 1919'da Ruslar Bayburt'u işgale hazırlanırken, Vehip Paşa ani bir kararla Ruslara karşı harekete geçerek Tercan dolaylarında 6 gün süren bir savaş ile Rusların Bayburt'u işgalini önlemiş̧i.

18 Haziran 1916 günü, Vehip Paşa, 5. Kolordu Komutanı Fevzi Paşa (Mareşal Fevzi Çakmak), Topçu Alayı Komutanı Albay Sabri Bey, Masat Deresi Komutanı Arslan Bey, Çoruh Müfreze Komutanı Binbaşı Halit Bey (Deli Halit Paşa) ve savaş sırasında bunlardan beşi yüzbaşı, on bir üsteğmen ve teğmenler Gümüşhane'de toplanmış, bu toplantıya Gümüşhane Mutasarrıfı ve Menzil Komutanı Abdulkadir Bey de katılmıştır. $\mathrm{Bu}$ toplantıda Rusların Trabzon'daki kuvvetlerine karşı bir saldırı yapılması kararlaştırıldı. 20 Haziran'da Fevzi Paşa, Akkoyunlu Yaylasına, 23 Haziran'da Vehip Paşa, Hart'a (Aydıntepe'ye) intikal etti. Buna bağlı olarak 16. ve 9. tümenler bu bölgeye intikal ettirildi. 9. tümen Gümüşhane Yağmurdere'de Mescit Yaylası batısındaki 
Şephane Köyü ve çevresine sevk edildi. 25 Haziran 1916'da harekât başlatıldı. Ancak, aynı gün Ruslar Bayburt tarafından harekâta geçince geri çekilmekte olan Rus Kuvvetleri 32. tümenimize ani bir gece baskını yaparak, Türk birlikleri arasındaki bütünlüğü bozdu. Bu savaşlardaki direnişin en önemli bölümünü teşkil eden Kop Savunması büyük bir zaferle neticelendi. Zira Rus General Yudenich bir direnişle karşılaşmadan, Erzurum'u kolayca işgal etmiştir. İaşesi kavrulmuş buğday ve arpadan ibaret olan Türk savunma hattı kırılınca, Dençik, Çimağıl ve civarında bulunan köylerdeki kadın ve genç kızlara asker elbisesi giydirilerek destek alan Türk kuvvetleri dört ay direnişi sürdürdü. Vehip Paşa, Enver Paşa'ya yazdığı bir mektupta; "Bayburt'u 2. Plevne yapacağım” demişti. Sonradan Mareşal Fevzi Çakmak "Büyük Harp ve Şark Cephesi Harekâtı" adlı eserinde "Bayburt muvaffak olmuş ikinci Plevne'dir" diyerek Vehip Paşa'yı onaylamıştır (San 1987: 24-25). Trabzon Limanı'na gelen malzemelerle silahların bir kısmı hamallar ve halk tarafından Turgun adını taşıyan arabalarla at, katır ve develerin sırtlarında Gümüşhane yoluyla Erzurum'a sevk edilmişti.

\section{Bayburt'un İşgali}

Türklerin 5. Kolordu Karargâhı Bayburt'taydı. Ruslar Kop Dağı eteğindeki Maden Köyünü ele geçirince Fevzi Paşa, karargâhı 15 Temmuz 1916'da Akşar'a (Balahor'a) nakletti. Rus Generali Yudenich'in Bayburt'u işgal etme planının Tercan saldırısı neticesinde bozulmasıyla 17. Türkistan Alayı Bayburt'a girdi. Öyle ki Başkomutan G. Nikola, Bayburt'un işgalini Çar'a büyük bir müjde olarak verdi. Rusya'da şenlikler yapıldı. Hemen ardından, Türklerin Trabzon hattında daha güçlü bir cephe kurmalarından endişe ederek "Türk Ordusu vakit geçmeden hemen ezilmelidir" emrini verdi.

17. Türkistan Alayı'na takviye olarak Kazak Alayı gelince, Mam, Niv (Arpalı), Zülfedağı-Yağmurdere'de savunma hattına yerleşen Türk askeri güçlerine karşı, bir yandan Uğrak (Varzahan) Danişman Köylerinin keşif kolları gözetlemeyi devam ettirilirken, diğer taraftan Çorak-Rüştü Köyleri arasından geçerek Sünür ve Mormoç ovasını hızla geçerek Köse üzerine yürüdüler. Rusların bu saldırıları karşısında Türk Ordusu'nun Çoruh Cephesi, Pulur-Gelinpertek hattına alındı. Hart Cephesi; Köse- 
Pirahmet hattının batısına çekildi. Lazistan Cephesi, Tekke-Gümüşhane ve Torul hattını tuttu. Sahil Müfrezesi, Kürtününfol Köyü-Vakfikebir deresine alındı (San 1987: 26).

\section{Gümüşhane’nin İşgali}

34. Tümen'in çekilmesi sonucu Ruslar boş ve savunmasız kalan bölgeden hareketle Kale Bucağını ele geçirerek Tercan Dağı (Köse) istikametinden Kırıklı Köyünü geçerek Pirahmet'e kadar girdiler. Pirahmet Köyü'nde uzun sürmeyen bir direnişle karşılaştılar. 19 Temmuz 1916 Günü Gümüşhane'ye girdiler. Gümüşhane'nin güney taraflarında Mezire Bağlarbaşı (Sorda) sırtlarında Türk Birlikleri uzun süre direndikten sonra Punpulak-Karamustafa deresine çekildiler. $\mathrm{Bu}$ olayların görgü şahidi olan Veli Çobanoğlu (Rüfeneli) Rusların Gümüşhane'yi işgalini 4 koldan gerçekleştiği ve bir alayın Koruş Dağı'ndan bir alayın ise Harava Dağları'ndan, bir diğer alayın Hayekse'den (Aktutan) Aşağı Yeşildere'ye indiğini, bir alayında Kızılköy (Çamlıca) başından aşağıya doğru taşındığını belirtmiştir (San 1987: 26-76).

\section{Torul'un İşgali}

Gümüşhane'nin işgali esnasında Torul Adliyesi mahkeme azası olarak görev yapan Sadi Selçuk “Esaretin Acı Hatıraları ve 37. Tümenin Trabzon'u Düşmandan İstirdadı” isimli eserinde mülkî işlerin durdurularak, memurlara askerî hizmetlerin verildiğini belirtmiştir. Cepheden gelen yaralılara mektep binaları tahsis edilerek, kendisinin bu işle görevlendirildiğini ve mutasarrıf Abdulkadir Bey'in askeri kıyafet giyerek bu yerleri teftiş ederek görev ihmali olanlara acımasız davrandığını ve düşmanın engelleri aşarak ilerlediğini ifade etmiştir. Ayrıca Trabzon civarında bulunan Zigana Dağı geçidine süvarilerin çıktığını ve bu düşman süvarisinin birkaç saatte Torul'u işgal edeceğini belirterek Torul Hükümet Konağı'ndaki mühim evrakların acilen çuvallara doldurularak üzerlerine Karahisar'a gideceğine dair yazdırıp, kiralanan atlarla (İkisuKodil) Nivene Vadisi'ni takiben Gavur Dağlarını aşarak Alucra'ya oradan da Karahisar'a gidilmesi emri üzerine kendisine sorgu hâkimi olan babası tarafindan görev verilip iki jandarma ve beş atla yola çıkarılmış ve ancak atlı saltatların (Rus askerleri) Hasköy civarında yakalanarak evraklarına el koyulduğunu ifade etmektedir. Punpulaktaki 28. Türk Alayı'nın 3. Taburu'na saldıran Ruslar, burayı ele geçirince 127. 
Rus Tümeni, İkisu-Ardasa arasındaki 18. Türk Tümeni’ni püskürtmek amacıyla 19 Temmuz 1916 günü Torul'u işgal ederek Trabzon yolunu açmışlardı.

\section{Kelkit'in İşgali}

9 Temmuz 1916 günü Ruslar'ın Türkistan 4. Avcı Alayları, erken saatlerde Kelkit üzerine saldırırlar. O gün akşam oluncaya kadar canla başla Türk direnişine rağmen Kelkit işgal edildi. Aksöğüt (Germürü) Köyü’ne bir alay Rus askeri yerleştirildi. Yine bu köye her gün beş uçak inip kalkacak şekilde, bir hava alanı inşa edilerek on adet uçak indirildi. Bu uçaklar, savaşın sonuna kadar bu köye inip kalkmışlardır. İşgalden sonra Rusların 2. Türkistan Kolordusu, Kelkit-Torul, 5. Kafkas Kolordusu, TorulTrabzon hattına yerleştirilmiş, buna karşı 3. Türk Ordusu, Trabzon-Erzincan hattına çekilerek savunma düzeni almıştır (San 1987: 28).

Gümüşhane işgal edilir edilmez Rus Komutanı iki bildiri yayınladı: İlk bildiride; "Bundan sonra Rusların kanunlarına uyulmasını din ve milliyet farkı gözetmeksizin herkesin eşit muamele göreceğini, can ve mal güvenliğinin sağlanacağını ve herkesin işinin başına dönmeleri gerektiği” istendi. Ancak, bu bildirideki ifadeler sözde kalarak, Rum ve Ermenilere destek sağlanırken Türklere zulmedilmişti. İkinci bildiride; “Askerlik çağına gelen ve Osmanlı Ordusuna henüz katılmamış ya da katılıp da kıtaya gitmemiş olanlarının isimlerinin ve bulundukları yerlerin bildirilmeleri" muhtarlardan isteniyordu. Bildiriye uymayan muhtarların ise idam edilecekleri özellikle belirtiliyordu" (San 1987: 28-29).

\section{Rus İşgali Esnasında Gümüşhane’nin Görünümü}

Torul Adliyesi'nde mahkeme azası olarak görev yapan Sadi Selçuk genç yaşında işgali yaşayıp önemli görevler ifa eden şahsiyettir. Bahsi geçen şahıs eserinde, istilaya uğrayan Gümüşhane'nin baştan başa ve sayılamayacak kadar yabancı bayraklarla donatıldığını, bu bayrakların Hıristiyan mahallelerindeki bina, pencere ve damlarına asıldıklarını, şehrin caddelerinde omuzlarında süngülü tüfekler bulunan saltatların gruplar halinde (Rus askeri) dolaştıklarını, yemyeşil çimenlerde otlayan atların kişnediklerini, tertemiz soğuk pınarlarında Rus askerlerinin neşeli şekilde su içtiklerini, ağaçların altında ise şarap içip âlem yaptıklarını anlatmıştır. Sorgu hâkimi olan 
babasının ise şehrin Daltaban mahallinde şehit edildiğinden, sıkıntılı durumda iken Ahıska Türkleri'nden, Erzurum'dan Trabzon'a kadar bütün Rus askerlerinin yiyecek ve iaşesininin temini ile görevli müteahhid Mahmut Bey (Kinyas) isimli şahsın kendisini bu durumdan kurtarıp Trabzon'a intikalini sağlayarak Cemaat-i Hayriye-i Islamiye adlı cemiyette çalışmasını temin ettiğini belirtmektedir. Buna benzer olayların cereyan etmesi Rus etkisi olsa da kardeşlik duygularının engellenemeyeceğini göstermektedir. Yine bu dönemde fes giyen yerli halk aşağılanırken Kafkas elbisesi giyenlerin ise Ruslar tarafından hoş karşılandığı Sadi Selçuk ile yerli halkın ifadelerinden anlaşılmaktadır.

İki dönem Gümüşhane milletvekilliği yapmış Sabri Özcan San, işgal esnasında çocuk yaşta olmakla beraber o günleri zihninde canlandırarak şu şekilde ifade etmektedir:

"Yazın ortas1 ortal1kta bolluk bereket var ki, otlar, ekinler bel boyu. Meyveler hevenk hevenk... Ama dalda meyve, tarlada ekin, çayırda ot kimin umurunda! Urus Geliy Çünkü! Herkes can kaygısına düşmüş. Geçimi düşünen kim... Korku heyecanı, göç hicranı düşmüş yüreklere. Kimi almış göçünü Amasya, Tokat, Çorum, Yozgat gitmiş. Kimi kaçmış dağlara. Ormana, mağaralara sığınmış. Yemekler ateş pişirilmeden hazırlanmış, dağlardan bahçelere gizli gizli inilerek meyveler, dutlar toplanıp tekrar dağlara çıkılır. Ağlayan çocukların ağızları kapatılır."

Hatta Raif Ağa isimli bir şahsın çocukların ağlamaları engellenemediğinde öldürülüp dereye atılmasını telaffuz ettiğini belirtmektedir. Ruslar'ın gördükleri ve hoşlarına giden her şeye el koyarak gasp ettiklerini, bahçelerdeki otları ve tarlalardaki arpa ve buğdayları biçip götürdüklerini, meyve ağaçlarını kesip hemen oracıkta yakarak kömür haline getirdiklerini, Vasili adında bir saltatın komutanın atlarını bahçelerde otlatırken halkın ondan 19 ay içinde Rusça öğrendiğini de, Türkistan alayları içindeki Tatar, Özbek, Tacik ve Kazakların da buluması ciheti ile Ermenilerin zulümlerinin nispeten önlendiğini belirtmektedir.

\section{Rusların Gümüşhane'yi Terk Etmeleri}

Rusya'da patlak veren ihtilalden sonra 18 Aralık 1917 'de Erzincan'da ateşkes anlaşması yapıldı. Ruslar, yerlerine Ermenilerden oluşan çeteleri bırakarak Doğu Anadolu'daki ordularını geri çektiler. Ancak, Türk direnişinin zayıf olduğunu bilen Ermeniler bu çekilmeyi kabul etmediler. Erzurum, Elazı̆̆g, Diyarbakır, Van, Sivas gibi illerin 
kendilerine ait olduğunu ileri sürerek Hıncak teşkilatı desteğinde katliamlara başladılar. Bunun üzerine Enver Paşa Türk-Kafkas Cephesi Komutanı Vehip Paşa’ya emir vererek 5 Şubat 1918'de Erzincan Mütarekesi'nin geçersiz olduğunu ilan edip, 3. Kafkas Ordusu'nu harekete geçirmiştir. Böylece, 15 Şubat 1918'de Gümüşhane ve Torul, 17 Şubat 1918'de Kelkit, 21 Şubat 1918'de Bayburt işgalden kurtarılmıştır (San 1987: 29).

\section{Rus İşgalinin Gümüşhane ve Çevre Halkı Üzerindeki Sosyal Etkileri}

Rus Genelkurmayı'nın Karadeniz Donanması Komutanı Amiral Eberhard'a gönderdiği bir mektupta “Kafkas Ordusu Trabzon’un İşgaline büyük kıymet vermektedir. Bu limanın işgal edilmesi gerek Erzurum'daki Türk Ordusu'nun ikmal yolunu kesmek gerekse Rus kuvvetlerinin gelecekteki ileri harekâtında bir ikmal limanı bulmak bakımından önemlidir.” der. (Bal 2011: 548).

Osmanlı Harbiye Nezareti Trabzon'un her an top ateşine tutulup işgalinin gündemde olduğu konusunda vilayet içindeki iaşe, yiyecek ve malzemelerin top menzilinin dişına çıkarılmasını emretmişti. 3. Ordu iaşesini temin etmek için görevlendirilen diğer vilayetlerin sevkiyat yapmaları yetersiz olduğundan Trabzon'daki erzakın Gümüşhane üzerinden Erzurum'a taşınması gündeme geldi. Konunun acil ve önemine binaen "Hamal Taburu"nun yanında Vali Cemal Azmi Bey ve sivil halk sandıkları sırtlarında taşımışlardır (Bal 2011: 561). M. Reşit Tarakçığlu'nun Trabzon'un yakın tarihi eserinde bahsettiği gibi çok çetin savaşlar vukuu bulmuş. Bunun da sosyal hayata yansıması olmuştur. Harşit Çayı'nın batı eteklerinde savunma hatları kuran yerli halk Ruslara geçit vermez. Hatta bu sırada Gümüşhane'de subay olarak görev yapan eski başbakanlardan Recep Bey (Peker) bu savaşta yaralandığında emir eri onu sırtına alıp düşmandan kurtardığını ifade etmiştir. ${ }^{1}$

Rusların Gümüşhane ve çevresindeki yerleşim bölgelerini işgalleri ve Trabzon'u bombalamaları ticari faaliyetleri yavaşlatmıştır. Avrupa ülkeleri ve diğer ülkelerle yapılan ithalat-ihracatın durma noktasına gelmesi, iflaslara yol açmıştır. Halk, açlıktan

\footnotetext{
${ }^{1}$ Ayrıca bkz. N. Monastarev (1948). Birinci Dünya Harbinde Karadeniz Cephesi, Çev. Afif Ertuğrul, Ankara: Deniz Basımevi; Tuncay Ögün (1991). Kafkas Cephesinin 1. Dünya Savaşı'ndaki Lojistik Desteği, Ankara: Dergah Yayınları.
} 
çeşitli hastalıklarla, hatta ölümlerle karşı karşıya gelmiştir. Dağlardan toplanarak yenen otlar yüzünden zehirlenip hayatını kaybedenler olmuştur.

Eski Gümüşhane'deki cami ve çeşmelerle Daltaban'daki çeşme tahrip edilmiştir. Benzer tahribatlar Bayburt ve çevresinde de meydana gelmiştir. Antika ve pahalı eşyalara Rus askerlerince el konmuştur. Cumhuriyetin kuruluşuyla bölgedeki sosyal-kültürel ve fiziki tahribat nispeten ortadan kaldırılıp toplumsal bütünleşme ve dayanışma sağlanmıştır. Diğer taraftan, bu savunmasız insanlar savaş bölgesini terk ederek kurtulacaklarını hesap etmiş ve yollar boyunca can ve mal kaybına uğrayarak sefaleti adeta sistemleştirmişlerdir.

Harşit Vadisi boyunca yerleşim bölgelerindeki savunmasız halk, özellikle genç kız ve kadınlar, erkekler cephede olduklarından dağ kovuklarına sığınıp zaman zaman tecavüz ve düşman tasallutundan kurtulmak için yüzlerini hayvan dışkıları ile koruma yoluna gitmiş̧lerdir. Sefaletin, yokluk ve açlığın sınırı yoktur. Yöre halkı güvenli bölgelere göç ederken çok acılı ezgiler dile getirmiştir. $\mathrm{Bu}$ acılı sahneler kadınlar ve erkekler tarafından dramatik şekilde terennüm edilerek günümüze kadar gelmiştir.

Ardasa'dan (Torul) çıktım başım selamet

Bayburt'a vardım ki koptu kıyamet

Anam, babam, bacım Hakk'a emanet

Seferberlik anca büktü belimi

Zalim Urus (Rus) yakt1, yıktı evimi (San 1987: 25).

Rus işgali ile meydana gelen göç olayı birçok ailenin yok olmasına sebep olmuştur. Geride kalan aile bireyleri ise değişik metotlara başvurarak hayatta kalmayı düşünmüş ancak yine de işkence edilerek şehit olmaktan kurtulamamışlardır. Bu işgalin Gümüşhane ve çevresinde toplumsal etkisi ve yöredeki insanlar üzerinde izleri çok belirgindir. Öyle ki muhacir olup çok az hayatî eşyalarını alıp yola koyulan, aç, sefil insanlar yorulduklarında can telaşıyla kundaktaki öz çocuklarını bile ölüme terk ederek çalı diplerine atma yoluna gitmişlerdir. Bu olay, Z. Metin YÜCE tarafından “Göç ve Muhacirlik" adlı şiirle özetlenmeye çalışılmıştır (Yüce 2015: 188-189).

Kağnılar gıcırdamıyordu yollarda.

Çalı diplerinde terk edilmiş kundaklar,

Suskun. 
Kanımız akmiyordu...

Figanımız dağı taşı tutmuştu.

Beli iki kat analar küskün.

Ciğerlerine ateş düşmüş ne çare,

Aldırmiyorlardi.

Erzurum sükut etti...

Derinden derine top sesleri,

Uğursuzluğu yankılandı.

Temmuz ayı cehennem ateşi sanki

Yapraklar sarard1.

Bahçelerde durulmaz gayri.

Yaylada çoban uykusunu yitirdi.

Ürktü davar1,

Gözleri karardı...

Yüreklerin en temizi ana yüreği,

Düştü yollara...

Göçmen kuşlar örneği;

Nerede konacağını bilmeden...

Yollar acıl1, yollarda herkes dertli.

Taşırken oğlunu sırtında,

Yoksulluk, ac1, soğuk ve karanlık

Sinmişti dağlara.

Yerleştiği kentte,

"Muhacir" olmanın ezikliğini,

Asker dolaklarına ördüğü düşüyle yenerdi.

İnanıyordu ki zafer,

İplik iplik atılarak,

Gerekirse tırnaklarla sökülüp kazılarak;

Kazanılacaktır.

Bu savaş sırasında Erzincan'da meydana gelmiş olan korkunç olaylar, özlemler ve yemyeşil bağların viran olması halk tarafından ağıtlaştırılarak şu şekilde dile getirilmiştir:

Erzincan'a girdim ne güzel bağlar

Erzurum'a vardım dumanlı dağlar

Elleri koynunda bir gelin ağlar

Oy anam anam, hallarım yaman

Yüce dağ başında çadır açarım

Nazlım seni alır burdan gaçarım

Gahve bulamazsam kenger içerim

Oy anam anam nasil dayanam 
Anama söyleyin lamba yakmasin

Çuha şalvarıma uçkur takmasın

Oğlum gelir diye yola bakmasın

Oy anam anam, hallarım yaman (Özürküt 2001).

Yine o tarihlerde Gümüşhane, Bayburt, Torul, Kelkit'te, Erzurum'da da benzer sahnelerin sergilenmesi şiirleşerek günümüze yansımıştır. Şehitlerin sayısı o kadar fazladır ki, Alansa Köyü (Kelkit) 10 şehit vermiş, bu durum ağıt şeklinde her yörenin özelliğine göre türkülere yansımıştır.

Alansa düzünde toplar atılır Ağır mermi havalarda tartılır Kimi şehit olur kimi kurtulur Seneler seneler zalim seneler Gide de gelmiye hayin seneler

Çocuklarını muhacirlik ve savaşta kaybeden babanın duyguları ise şu şekildedir:

Bir sandığım vardı, sirmadan telden

Bir çift yavrum vardı tomurcuk gülden

Nasıl ayrilayım gül yüzlü yârden

İşte şöyle böyle hal deli gönül

İster ağla, ister gül deli gönül

Bir yanım Erzincan, vermem Bayburt'u

Yıkılsın düşmanın taht ile yurdu

Sağ olasın anam, beni doğurdu

Seneler seneler kötü seneler

Gide de gelmiye, zalim seneler

Faytonlar geliyor üstü pareli

Askerler geliyor bağrı yareli

Kimimiz nişanll, kimimiz evli

Sene gardaş sene, ille bu sene

Gide de gelmiye, hayin bu sene

Akşamdan yükleri, tay eylediler.

Sabahtan öküze "Ho" eylediler. 
Memleket satıldı pay eylediler.

Sene gardaş sene ille bu sene

Gide de gelmiye, bu hayin sene.

Gümüşhane ve çevresi yaklaşık 2 yıl esarette kaldıktan sonra Rus işgalinden kurtuluşa ulaşılmış ve bu durum ise halk tarafından sevinçle karşılanmış ve türküleştirilmiştir. Türkü ve ezgilerimizin yanında, Rus işgalinden kurtuluşta yöre halkı üzerinde sevinç duygularını kabartmıştır. Buna bir örnek verecek olursak, 15 Şubat 1918 günü Gümüşhane'yi terk eden düşmanın bu hareketi halkı coşturmuştur. Bu heyecana tercüman olan Z. Metin Yüce (Yüce 2015: 190-191) bu sevinci aşağıdaki şiirinde dile getirmiştir:

\section{Kurtuluş Günü}

Kop Dağları'nda

Ölümün şiiri yazıllyordu,

1916 yılında.

Dutlar, vişneler, erikler elmalar,

Tüm tohumlar

Haksızlığa direnmektedir.

Dallar, meyveler toprakla birlikte

Yaşamı bayrak bayrak bestelemektedirler.

Çimenlere düşen alınlarımızın yüreklerinde,

Sözlerimiz

Kar bulutlarının yücesinden,

Ak ve parlak...

Kurtuluşun inancında.

Gözlerimiz

Yildizlarda, yurt ve bayrak.

O yılın temmuz ayında,

Harşit Çayı,

Haksızlığa karşı

Beslenerek en gür kaynaklardan,

Bin bir kahırla iniyordu.

Daltaban'daki şadırvan

Yüreğimizin başına oturtmuştu!

Ayrılı̆̆ın acı türküsü söyleniyordu...

Gözlerimizde ölüm korkuya durmuştu

Mehmetçik'in süngüsü,

Gelincik tarlalarında,

Bizi saran bayraktı.

Özgürlüğün gönül birliği,

Vatand1... 


\section{Kara Günler}

Yurt sönmüş, yurttaş bitmiş her yer olmuş harabe,

Taş olsa dayanamazdı böyle bir 1stıraba

Her evden birkaç şehit Köprüköy'de Horom'da

Hicret edenler ölmüş Kayseri'de Çorum'da

Yurtta kalan kuşanmış esaret zincirini

Gençler mekân edinmiş yer altı inlerini,

Aranır köşe bucak, ne varsa şişlenerek

Talan edilir sandık, sepet, kırıp dökülerek

Camiiler hep kapanmış, pislik edilmiş mabet

Ne ezan sesi kalmış, ne namaz, ne ibadet

Aş ekmekten eser yok, millet hayattan mahrum

Namus düşmanlarının önderi yerli mel'un...

Şeklinde uzayan Muhacirlik-Göç Destanı'nı yazan Süleyman Sungurlu, Gümüşhane ve çevresindeki yokluk, kıtlık, vefasızlık, arkadan vurulma gibi olayları destanlaştırmıştır. Yukarıdaki ifadeler bize Türk milletinin vatan sevgisini her şeye rağmen devam ettirdiğinin göstergesidir. Yine "Sahipsiz vatanın batmasının hak olduğu" inancı bu savaşlar sırasında gerçek boyutuyla ispat edilmiştir. Nitekim peygamberimiz de (s.a.v) vatansız insanların imanı olamayacağını, yani vatan sevgisinin imanın göstergesi olduğunu ifade buyurmuştur. $\mathrm{Bu}$ destansı mücadeleyi yapan insanların faaliyetlerini türküler, ağıtlar ve destanlar şeklinde yeniden dile getirmiştir. Bu olaylar büyük kayıplara rağmen, gönül kırıklığı yerine sadece fedakârlığı seçmiş olan halkımızın mücadele azminin ifadesidir...

\section{İşgal Sırasında Sivil Halkın Rus Askeriyle Münasebetleri}

Dünya Savaşı sırasında Ruslarla Ermenilere karşı teşkilatlanan halk duygularını şu şekilde ifade etmiştir. Hatta bu konuda çocuklarını bile feda etmeyi göze alan insanımız işgalden birkaç gün önce "Gelin komşular çoluk çocuğu vurup dağa çıkalım, bizde vuruşa vuruşa ölelim." ifadesi çerçevesinde mücadeleyi seçmişlerdir (San 1987: 58; 2014: 185). Savaş sırasında, halkın lideri zannedilen Ömer Ağa teslim olmasına rağmen süngülenerek şehit edilmiştir. Bu sahneleri, olayı yaşayanlar şu şekilde açıklamışlardır:

"Gece gündüz demeden iri katırların çektikleri savaş arabaları geçiyor. Arabacılık yapmakta olan Malakanlar başlarında, mor koyun derisinden yapılmış, uzun tüylü başlıklar ile uzun kınalı sakalları olan değişik tiplerdi. Rus askerleri kışın koyun postundan topuklarına kadar uzanan kürkler giyerdi. Ayaklarında ise kalçalarına kadar uzanan su geçirmez ve soğuk işlemez kalın keçe çizmeleri vardı. Cep sobasına benzeyen bedeni isırtacak özellik taşıyan bir aleti o zaman Rus askerlerde 
gördüm. Savaşan Türk askerleri Allahuekber Dağlarından Sarıkamış’a, Soğanlı, Dumlu, Kop Dağı'na kadar bütün imkansızlıklara rağmen işte bu sırtı pek, karnı tok askerlerle mücadele etmek zorunda kalmıştı. Bu da bir anlamda adeta imkânla imkânsızlı̆̆ın savaşı gibiydi. Arabacı Malakanlar ise, nerede konaklıyorlarsa orada semaverleri yakmaktaydı zira onlar çaya çok düşkünlük gösteriyorlardı. Karnel adlı bakır kovalarla karavanaları taşıyarak, tahta kaşıklarla yemeklerini yerlerdi” (San 1987: 62).

Bu olayları henüz 5-6 yaşlarında görüp yaşayan Sabri Özcan Bey ifade etmiştir.

Rusya'nın yayılma politikasının özünde Gümüşhane'yi işgal etmekle başlayan faaliyetlerinde amaçlarını gizlediklerini ve genel hedefin ise sıcak denizlere inmek ve İstanbul'u ele geçirmek olduğunu göstermektedir. Ruslar kolay hareket etmek için işgal ettikleri her yerleşim alanına yol, köprü yapmış, bu bağlamda Petro'nun politikasını gerçekleştirmek istemişlerdir. Cenevizlilerden kaldığı bilinen Canca, Kov (Esenyurt) Kalesi, Keçikale gibi yapıların o tarihlerde ticaret yolu olarak bilindiklerini, iktisadi, askeri görevler için kullanıldıklarını, haberleşme amacıyla faydalanıldığı bilinmektedir. Bölgeyi işgal ederken bu kalelere yol yapmaları bize Rusya'nın Trabzon limanından Orta Asya’ya açılan kapıyı kontrol etmek amacında olduğunu göstermektedir. Gümüşhane merkez Yenice Köyü ve çevre köylerde bulunan ot toplama ve balyalama aletlerinin ve katırların yiyeceklerini temin etmek maksadıyla birçok depoda yiyeceklerle mühimmatların saklandığı anlaşılmaktadır. Bu alet ve makinaların halen Yenice ve Nazlıçayır Köylerinde bulunduğu olaya şahit olanların ifadelerinden anlaşılmaktadır. Rusların savaş mimarisi ile teknolojisini gören sivil-asker bütün Türkler başarısızlığın sebebini bu noktada görerek rapor haline getirmişlerdir.

\section{SONUÇ}

Yukarıda kısmen ifade edildiği gibi, Rus-Türk savaşı boyunca insan hafızasını zorlayan olaylar cereyan etmiştir. Mesela, yaşlılar, kadınlar ya dağlara sığınmış ya da feci şekilde ölümü seçmiştir. Örneğin, yaşlılar ellerindeki imkânlarla direnişe yardımcı olmaya çalışırken birçoğu soğuk ve açlıktan canlarını vermişlerdir. Kadınlarsa çoğunlukla kendilerini Çoruh Nehri ile Harşit Çayına atarak namuslarını kurtarmış ve ölümü seçmişlerdir. Bir kısmı da "Denize düşen yılana sarılır" özdeyişine paralel olarak düşmanın yardım talebini kabul edip suikaste uğrayarak yine can vermişlerdir. Cephe 
gerisindekilerin ise bir kısmı düşmana yardım yoluyla hayatta kalacaklarını zannederek, yüz kızartıcı davranışlarda bulunmuşlardır. Hatta bu insanlar canlarını kurtarmak adına mal ve mülklerini geride bırakarak adeta sefaletle kucaklaşmayı tercih etmişlerdir. Asırlarca Müslüman Türk milletinin engin hoşgörüsü ve güvencesi altında yaşayan Rum köylüleri ise usulen Türk komşularını teselliye çalışır görünerek Rusları karşılamak için hazırlıklarda bulunmayı ihmal etmemişlerdir. Hatta ömürlerinin büyük kısmını Rusya'da geçiren bazı Rumların düşmanın gelmesinden memnunluk duydukları da açıkça görülmüştür.

Çarlık Rusya'sı Sovyetler Birliği’ne "Panslavizm”i en büyük miras olarak bırakmıştır. Rusya'nın değişmez ideali olan bu hedef yaklaşık iki asırdan beri idarecileri yönlendirmiştir. Bu tür faaliyetlerin temelinde Büyük Rusya ideali ile sıcak denizlere inme ve Ayasofya'nın alınması yatmaktadır. Birinci Dünya Savaşı ile sonuçlanan süreçte Türkiye'yi milyonlarca kilometre kareden yedi yüz seksen bin kilometre kareye düşüren Türk-Rus mücadelesinin diğer bir hedefi de "Panslavizm" ideolojisidir. İki yıla yakın bir süre içerisinde işgal edilen bölgelerde hala istikan (bardak) kelem (lahana) vb. gibi kelimeler halk tarafından kullanılmakta olduğu Rusların halk üzerindeki tesirinin göstergelerindendir.

Ruslar Türk halkına karşı hoş görünebilmek için yumuşak ve merhametli davranış yolunu seçerek ileriye doğru yatırım yapmayı plânlamışlardır. Nitekim küçük çocukların ve bazı aciz yaşlıların onore edilmiş olmaları bu niyeti doğrulamaktadır. Bu konudan olmak üzere İbrahim adını alan Rus Bando Şefi Gümüşhane’ye yerleşip burada kalarak Türklerle kaynaşma yolunu seçmiştir. Yine Ruslar Rum asıllı Mumcidis Efendi’yi Gümüşhane Belediye Başkanı olarak atayarak teşkilatçılık ve güç bakımından üstünlüklerini ortaya koymaya çalışmışlardır. Keza Rus ordusunda bulunan bir kısım Tatar ve Kazak askerlerine baskı yapılarak Türklerle konuşturulmayışı bu görüşümüze teyit edici niteliktedir.

Ruslar Gümüşhane ve çevresinde altın ve gümüş yataklarının bulunduğunu önceden bildiklerinden Gümüşhane işgalini uzun süre devam ettirme niyetindeydi. Onun için Rus ordu karargâhı Gümüşhane’ye de kurulmuştur. Bugün ABD’nin enerji kaynağı olan 
petrol bölgelerini çeşitli bahanelerle işgal etmesi, Rusya'nın değerli madenlerin bulunduğu Gümüşhane'yi işgaliyle benzerlik taşımaktadır. Savaş yıllarında halkın sefaletine rağmen Rusların bölge üzerinde hâkimiyetinde 1srar etmesinin en önemli sebebi bu olmalıdır. Rus askerinin sayı ve donanım bakımından üstün olması bizim bu konularda yetersizliğimizi ispat etmiş ve savaş meydanlarında bile teknik-iktisadi üstünlüğün zaferleri taçlandırdığını açıkça göstermiştir. İşgal sırasında başarısızlıkların sebeplerini şöyle özetleyebiliriz: Halkın hazırlıksız yakalanması, ordunun silah ve mühimmatının yok denecek kadar az olması, teknoloji yetersizliği, komuta merkezleri arasında koordinasyonsuzluk, ulaşım imkânsızlığı, Zigana, Vavuk, Kop ve Pöske Dağı gibi fiziki engeller. $\mathrm{Bu}$ durum savaş meydanlarında bile teknik-iktisadi üstünlüğün zaferleri taçlandırdığını açıkça göstermiştir.

\section{KAYNAKÇA}

BAL, Mehmet Akif (2011). “Trabzon'un Rus Donanmasına Bombardımanın Trabzon'a Etkileri”, Atatürk Araştırma Merkezi Dergisi, 27(81): 545-576.

Birinci Dünya Harbinde Türk Harbi Kafkas Cephesi (1993). 3. Ordu Harekât1, 1-2, Ankara.

KURAT, Akdes Nimet (2014). Rusya Tarihi, Ankara: TTK Basımevi.

LERMİĞLU, Muzaffer (2011). Akçaabat Tarihi ve 1. Genel Savaş, Hicret Hatıraları. ÖKSÜZ Hikmet ve Veysel USTA (2008). M. Reşit Tarakçığlu Hayatı ve Hatıratı, Trabzon'un Yakın Tarihi, Trabzon: Serander Yayınları.

ÖZOL, Sabahattin (1991). Milli Mücadelede Trabzon, Ankara: TTK Basımevi.

ÖZÜRKÜT, Yaşar (2011). Öyküleriyle Türküler, İstanbul.

SAN, S. Özcan (1987). Rusların Gümüşhane İlini İşgali, Ankara: Meb Yayınları.

SAN, S. Özcan (2014). Vadideki Gümüşhane, Trabzon: Gündüz Ofset Matbaacılık.

SELÇUK, Sadi (1955). Esaretin Acı Hatıraları ve 37. Kafkas Tümeninin Trabzon'u Düşmandan İstirdadı, Kurtuluş, Konya: Ülkü Basımevi. 
SONYEL, R. Salahi (1997). Türk Kurtuluş Savaşı ve Dış Politika, Ankara: TTK Basımevi.

Türk Ansiklopedisi (2001). 15, İstanbul, MEB Yayınevi.

YILDIZ, Yılmaz (2007). Atatürk İlkeleri ve İnkllâp Tarihi, Ankara: Nobel Yayınları.

YÜCE, Z. Metin (2015). Memleket Şiirleri, İstanbul: Tutya Dizgi Matbaacılık. 